\title{
A CAPABILITY TO PROMOTE THE COMMON GOOD
}

\author{
Paulus Bambang Irawan
}

\begin{abstract}
:
Capability Approach yang dikembangkan oleh Martha Nussbaum dapat memperkuat landasan antropologis dalam berbagai usaha mewujudkan kesejahteraan umum (bonum commune) dalam masyarakat plural. Dengan pendekatan induktif dan pengakuan akan kemampuan dasariah manusia untuk selalu berkembang, Capability Approach menunjuk pada pluralitas bentuk kebaikan yang oleh Nussbaum dieksplisitkan dalam sepuluh bidang kemampuan dasar manusia (basic capability), terutama penalaran praktis dan afiliasi. Di satu sisi, pemberian ruang bagi tumbuhnya kesepuluh kemampuan dasar tersebut adalah ambang batas (threshold) bagi terwujudnya kesejahteraan umum dalam masyarakat plural. Di sisi lain, prinsip kesejahteraan umum dapat memperkuat perspektif komunitarian dari kemampuan untuk memilih (choice) yang mendapat peran sentral dalam Capability Approach.
\end{abstract}

Key Words:

capability approach, the common good, participation, affiliation, community, choice

After the publication of Amartya Sen's Development as Freedom, ${ }^{1}$ the capability approach gained much attention for giving a broader conception of development. Alongside with Martha Nussbaum in the field of political philosophy, the capability approach endeavors to show the inadequacy of major economic thinking on development. To assess the quality of life, we must focus on the question of what people are capable to do and to be. The United Nations in their annual Human Development Report documented this paradigmatic shift.

If we read carefully the capability approach proposed by Amartya Sen and Martha Nussbaum, we can find a clear intersection with the principle of common good in the Catholic social tradition. It is quite understandable, because both of them originate from the Aristotelian view of the good society. Aquinas' reading on Aristotelian metaphysics heavily influences the classic understanding of the common good. On the other hand, Martha Nussbaum bases her proposal on ten central capabilities in her reading of politeia as Greek social democracy. ${ }^{2}$

In that powerful intersection, this paper seeks some coherence between these two approaches and to point out their divergence on the role of choice in the societal context. I make three conclusions from this dialogue.

a. The common good tradition should use the capability approach to strengthen their anthropological stand. In this pluralistic society, the modern interpreta- 
tion of the common good should be inductive in its method and should respect the different idea of goodness within and among cultures. The idea of perfection and natural law as the foundation of the common good should be interpreted inductively and not deductively. The capability approach with its strength in inductive reasoning for tracing various areas of human capability can give the common good theory the anthropological strength and background to understand the idea of perfection and natural law in this pluralistic world.

b. The common good and the capability approach assure the human capability to communicate and to build common understanding through intellectual solidarity. Both theories come from the Aristotelian conviction that human beings are social in nature. Therefore, human beings will seek each other to create communio (common good theory) or affiliation (Nussbaum). Both theories also affirm the importance of participation as the community's inner dynamic to create a better society. In this situation, intellectual solidarity can be defined as the disposition to strengthen multicultural affiliation.

c. Human freedom, as a fundamental entitlement in capability approach, and community are not in vis-à-vis opposition. Human being performs his freedom in the community, and the role of community is to foster people's ability to choose the better way to flourish as a person. The phenomenology of language affirms the relation of freedom and community. The capability approach should draw the richness of cultural embeddedness to understand the societal context of human freedom from the common good tradition.

This paper consists of three parts. The first part surveys the development of the common good theory from Thomas Aquinas to the modern reappraisal in the context of multicultural society. The second part presents the Aristotelian trajectory in Martha Nussbaum's theory of capabilities and the applicability of Aristotelian human flouris- hing in social democracy. The third part assesses the convergent and divergent point in dialoguing the notion of the common good and capability theory.

\section{PART I - THE ON GOING TRADITION OF COMMON GOOD}

\section{Tracing the Origins: Thomas Aquinas on Common Good}

The Western tradition is very familiar with the concept of the common good as the normative vision of good life in the community. However, it is not easy to find a comprehensive definition of this concept in the Greek classical moral philosophy, European Christian theology, or early modern Christian spirituality. ${ }^{3}$

Roughly speaking, there are two major approaches in Catholic theology in dealing with the world, Augustinian and Thomistic. Augustine, influenced by Neoplatonism, views the world of creation deeply impacted by sin, where the human ability to percept reality is easily fooled by disordered human lust. Grace is important in helping corrupted human beings to discern the will of God. On the other hand, Aquinas uses the Aristotelian conviction that the world of senses provides a wide opportunity to develop various human goodnesses. Human beings have rationality to discern the ultimate truth because the world is locus revelationis of truth. Aquinas does not neglect the reality of $\sin$, but he believes in the human capability to grow in the journey to know the good. On this very point, he lays out his teleological vision of good. ${ }^{4}$ Aquinas uses the Aristotelian hierarchical pattern of existence to show the interconnectedness of the good. Since God is the ultimate good, this hierarchical pattern will show that everything, from the most simple to the most complex entities, participates in God's goodness in their own degree.

This term participation is very important in Aquinas metaphysical thinking. Aquinas describes participation as partem capere (taking part of something) and partem habere (having a part from something). Aquinas says that "to parti- 
cipate is like taking a part; thus when something receives a part of what belongs to another fully, it is said to participate in it". ${ }^{5}$ Take an example: hot soup comes from two different entities taking part in each other, the soup and the heat. There is mutuality between these two entities; then participation can be looked from the one who participates (the soup) or from the position of which it will participate (the hot). It is the relation of giving and taking part. By this mutual relation, Being moves toward its telos, to perfection.

In De Veritate, Aquinas write "since the essence of good consists in this, that something perfects another as an end, whatever is found to have the character of an end also has that of good. Now two things are essential to an end: It must be sought or desired by things which have not attained the end, and it must be loved by things which share the end, and be, as it were, enjoyable to them." "On the one hand, for a thing to exist, it must exist in participation to perfect something else, to assist the other to their fullness. But, on the other hand, if someone wants to participate in the process of perfecting another, she must "love" the thing that she wants to share and put it as her own goal. On this way, the dynamic of giving and taking is preserved. The human law then must incorporate and secure this dynamic inclination to perfection in the society. ${ }^{7}$

By that fundamental reason, Aquinas claims that the human being is not just an animal rationale but also an animal sociale. Maritain proposes three reasons for this claim. First, humans have an ability to love and communicate with other. This internal drive urges them to find and relate with other humans. Second, because of their material inadequacy, human beings interact with each other to gain their basic needs. Stepping aside from society means cutting away the resource for their needs. Third, in order to develop their ability and to fulfill their vocation to perfection, human beings needs to learn from society, especially by education. ${ }^{8}$

In this rich notion of Thomistic metaphysic, we can understand deeply Mater et
Magistra's definition of the common good as "the sum total of those conditions of social living, whereby men are enabled more fully and more readily to achieve their own perfection." ${ }^{2}$ The common good is a field of participation for perfection in the society. A person must relate and participate with other persons to attain their fullness of life. They cannot live alone in society, and society will help them by setting up "those conditions of social living" so they acquire their basic needs to flourish.

\section{Modern Appraisal of the Common Good}

Still departing from Aquinas' thinking on the common good, modern interpreters use several approaches in addressing the notion of the common good. The first approach is equating the common good with public good or public service. There are two characteristics of a public good/ service. First, it is nonrivalrous in consumption. We do not need to conflict when we use it. ${ }^{10}$ For example: a beautiful beach is a public good. When someone enjoys this beach, other people have the same right to use it. The other characteristic of a public good is that it can be enjoyed by everyone without exception (non-excludible). For example: clean air is a public good because everyone can enjoy it. However, clean air in gas cylinders is excludible, because only the one who buys the cylinder can legitimately enjoy it. Since the public good should be available to everyone, the benefits of public goods should not be reserved to individuals/ groups only.

The second approach to the notion of the common good focuses on the internal conditions of society that make every member of the community participate and contribute to a shared public good. This approach echoes Gaudium et Spes' definition of the common good as "overall conditions of social life, which allow both groups and individual members, to achieve more fully their own perfection."11 According to this line of thought, the quality of human relationship is more important than the public good itself. Society can provide the public good if only their members commit themselves to make those goods open to the 
public and not just for private consumption. Consequently, being a member of a community (commune) itself is a form of goodness (bonum). Members of the community are "non-rivalries" and "nonexcludible" in sharing the public good because there are connections characterized by mutual respect.

The new understanding of pluralism urges the common good theory to answer the new challenge: why does modern pluralist society need to listen this ancient notion of the common good? Hollenbach states three reasons for a pluralist modern society to pay attention to the concept of the common good. ${ }^{12}$ First, the fact of pluralism in all aspects of our life invites society to find a new philosophy that pays more attention to the relations and cooperation among human beings. Tolerance has been glorified as the highest value in a pluralist society, but it fails to answer the new questions that arise. We cannot address the question of AIDS in Africa or global warming merely by tolerance. Cooperation and human relation provide a new key factor in addressing our common problem. Second, there is a new awareness that the concept of identity is found through interaction within tradition and between communities. The personal search for liberty disconnected from the network of human relations is not an adequate basis for the concept of human identity. Third, globalization and new economic practices underscore the importance of interdependence between human beings. Economics is not a "solo activity" but an activity in the community for the common good.

Because the common good encompasses all conditions that make each person or group reach her fullness and work together to interpret the good life, Hollenbach then proposes the concept of intellectual solidarity as a precondition for building the common good. He defines intellectual solidarity as "an orientation in mind that appreciates differences between various kinds of tradition as a stimulus for intellectual engagement beyond the limits of religious and cultural boundaries." 13 There are a couple of constitutive elements in intellectual solidarity. First, intellectual solidarity is the process of deliberation that requires the principles of reciprocity and is supported by the attitude of civility. Second, human rights are an institutionalization of human solidarity; and human freedom itself is not defined only as negative freedom (e.g. freedom from fear and coercion) but also as freedom to promote the goodness in society. This freedom manifests itself in the willingness to engage in the public sphere.

\section{The Common Good and Communio}

As Maritain has said, the common good is not a collection of private goods. It is impossible to put all private goods under one big umbrella called the common good. The common good is built through consensus and active involvement of all members of the community. In this case, intellectual solidarity has an important role in creating a sense of connection between members of the community, and then facilitating mutual networking and empowerment.

It is clear that the common good can only be built in a community because only in the community, we can establish and maintain the agreements on living together. Willingness to build community is essential for the achievement of the common good. Critiques of liberalism clearly point out the tendency of modern man to live alone and to be reluctant to live in an active community. ${ }^{14}$ It is ironic that when the world becomes more interconnected, the quality of human relations receives less attention. People may live freely just next door, but it is difficult to treat them as brothers. Therefore, modern Catholic thinkers identify human relations as a major dimension for interpreting the common good for this pluralist society. Creating conditions that allow each individual/ group to reach their fullness starts from encouraging the willingness of all members to live in the community. Without such awareness, it is impossible to avoid political realism, a view that every political effort does no more than satisfying certain group interest.

Hollenbach quotes Cicero's statement in stressing the importance of finding a 
sense of relation in this pluralistic world: "Res publica, res populi, populus autem non omnis hominum coetus quoquo modo congregatus, sed coetus multitudinis iuris consensus et utilitatis communio societatis" ${ }^{15}$ For Cicero, the republic is a matter of the people. The people are not just individual person assembled together in one place, but they constitute the togetherness of the people in recognition of the law and in participation in public interests. So, iuris consensus (consensus about the law) and communio utilitatis societatis (communio that meets the interests of its member) are the keys in community life. Living together must become a communio. It means citizens meet and talk to each other about public issues. Therefore, participation is required. Tolerance proves to be insufficient as a modus vivendi in a pluralist society because tolerance cannot solve complicated problems that occur in our world, such as poverty and environmental destruction. Globalization on the one hand can widen the gap between the rich and the poor because the poor do not have equal access to capital. But on the other hand, with globalization, mutual cooperation can increasingly grow through global networking.

\section{PART II - ARISTOTELIAN TRAJECTORY IN CAPABILITY APPROACH}

\section{Overview of the Capability Approach}

Amartya Sen firstly proposed the capabilities approach in the context of developmental studies. In his Tanner Lecture, Sen criticized John Rawls' theory on the distribution of primary goods. Rawls puts more focus on how to make the just principle in distributing the primary good, but he does not acknowledge the discrepancies of people in accessing those goods. Take an example of people with disabilities. The first Rawlsian principle of just distribution will assure that they will get the same amount as other members of the society. But because of their disability, they will struggle much more (e.g. limited by their wheel chair movement) in assessing the good. Finally, they will get much less amounts of public goods compared with other members who don't have the same obstacles. Similarly, accessing drinking water in the African dessert will require more efforts with small result than with Bostonians who can easily get good tap water in their kitchens. So, rather than establishing a basic principle for distributing the basic goods, it is more important to promote the basic conditions in such a way that people with his different background and difficulties can have better accessed to the basic goods.

The capabilities approach is also well aware of utilitarian reductionist tendency in viewing development in terms of the fulfillment of people's desire. ${ }^{16}$ Utilitarianism fails to recognize that the richness of basic goods cannot be assessed as maximizing people's happiness as the single metric criteria. The notion of desire and happiness is deeply embedded in the social construction of culture. For very wealthy people, happiness means buying luxurious jewelry, and for the working class family in Indonesia to eat chicken twice a week is already a blessing. Nussbaum and Sen show that women in repressive cultures are prone to adapt to and accept the unjust condition and incorporate it as a new value, because it is hard for them to break the cultural chain. The utilitarian development approach fails to recognize this "adaptive preference" in viewing human happiness.

Providing greater access in development starts with the answer to this basic question: what are people actually able to do and to be? By entering the space of capability, we can grasp a better understanding about social justice and equality and also how society should manage their resources to secure these goods. Sen and Nussbaum have a different tone when talking about capability as a basic measure to assess development. While Sen focuses more on the comparative use across nations as presented in the United Nations of Development Program since 1990, Nussbaum put her attention on the constitutional process in which citizens can ask the government to secure a threshold for them to live decently. 


\section{Aristotle on Just Distribution and Capabilities}

Influenced by Aristotle and Marx, Nussbaum states that the political arrangement must rest on the priority of good. ${ }^{17}$ For Aristotle, political arrangements have two categories: broad and deep. Broad means they are open to everybody, not just a few elite or rich people. They are deep, because political arrangement is not just concerned about distributing material good but also with "totality of the functioning that constitute the good human life." 18 Due to the broadness and depth of political arrangements, Aristotle sees that goodness has an instrumental feature. Goodness becomes the context that gives meaning to the certain activity. Aristotle use a simple question in contextualizing the good: "what for?". Wealth -for example- has a meaning for certain activity like "buying and selling". Everything has a purpose for something. So, in making a priority of the good, we cannot separate the goodness from its context, its specific end. Since goodness always exists in a context, it is the duty of the lawgiver to make the distribution related to the context of the people. In other words, the lawgiver must address the particularity of the people in the polis. Acknowledging particularity prevents someone for getting too many resources and others getting less. This is a form of "just distribution" in Aristotle's era.

Nussbaum relates the "just distribution" theory from Aristotle as differentiating between polis and oikos. One major difference feature between city and household is how to handle plurality. The city recognizes and preserves plurality, but the household doesn't. Plurality arose from the sense of togetherness. In this case, togetherness is not defined as wholeness but as being together in caring for each other. For Aristotle, togetherness in caring for each other is the foundation of just distribution. It acknowledges plurality and difference between people, but at the same time, it sets social arrangement so that the lower level of society can get enough resources to function well.
In relation to the deep characteristic of political arrangements stated above, the distribution theory in Aristotle is more than the allotment of commodities. Distribution relates to the flourishing life, to strengthen the capabilities in human beings. For Aristotle, the aim of political arrangement in the polis is setting various conditions for citizens to choose and live a good human life. ${ }^{19}$ It is the job of the lawgiver to consider how society can help people to live flourishing lives, to create a context in which a person can choose. ${ }^{20}$

But, what is capability in Aristotle? Nussbaum finds three different notions of capabilities: internal capabilities, external capabilities, and combined capabilities. $^{21}$ Internal capabilities refer to any activity that treats people in such a way that they can act and choose well for their flourishing life. It is a basic capability that makes other capabilities grow. For example: the polis will arrange public funding to help the people from all classes to get better food and education. ${ }^{22}$ The twofold reasons behind this arrangement are: through proper meals, people -especially the youth- can get the basic "nutrition" to grow and healthy; by good education, they can get best training to reflect their role or function (ergon) in the society. Proper food and education are basic capabilities for human flourishing.

External capabilities refer to social conditions that make internal capabilities able to grow. One example is time for leisure. The polis makes an arrangement that people do not get trapped in endlessly repetitive work and have enough time to care for their own bodies. The other external capability is political participation. In Politic 1329b39 ff, the common meal is a form of social engagement, "and all citizens should participate in them, but it is not easy for the poor people to bring in the required contribution and to manage the rest of their household affairs". It is interesting how Aristotle proposes the solution for this discrepancy on the capability to engage in social activity. He proposes to make a land reform, so that there will be enough public funding to support the poor to engage in 
the common meals, and also in religious festivals. The private ownership is still kept but the polis tries to manage how to support the poor by a kind of "public funding" in order that they will still be able to participate in public. ${ }^{23}$

The combined capability is defined as "internal capabilities plus the social/ political/ economic condition in which functioning can actually be chosen." ${ }^{24}$ Of course, we cannot make a sharp distinction between internal capability and combined capability since developing internal capability needs social arrangements that make it possible. Later on, Nussbaum develops this combined capability as ten central capabilities, which will be presented in the next part.

Nussbaum claims that her theory of capabilities is freestanding from any metaphysical doctrine or epistemology, from religion or anti religion. Influenced by her Marxist reading of Aristotle, we can get the intuitive idea of human dignity from "sensitivity to the actual circumstances of human life and choice in all their multiplicity". For Marx, the plurality of human activities shows that human beings are not just the "herd" of a "flock." We are not animals that only eat and breed. We are guided by practical reason and longing for sociability. Education nurtures our ability to use our senses, invests time for leisure and enjoyment of play. She called this method of reasoning "internalist essentialism", which is basically Socratic questioning in order to determine what is indispensable and the minimal quality of life to be called a human being.

\section{Ten Central Capabilities as Basic Threshold for Human Dignity}

From that Aristotelian legacy, Nussbaum in a later publication proposes the "open-ended" list for societies to get the over lapping reference about our basic capabilities. Starting from this list, society can demand the government to protect it in its constitution. One major difference between Sen and Nussbaum is Sen leaves the capabilities approach in a more formal way and leaves the specific directives of the capabilities to be determined by the community. Nussbaum claims that she is going beyond Sen by proposing these ten central capabilities as a threshold for being accommodated in the constitutional process. The ten capabilities are:

1. Life: being able to live to the end of a human life of normal length; not dying prematurely, or before one's life is so reduced as to be not worth living;

2. Bodily health: being able to have good health, including reproductive health; to be adequately nourished; to have adequate shelter.

3. Bodily integrity: being bale to move freely from place to place; to be secure against violent assault, including sexual assault and domestic violence; having opportunities for sexual satisfaction and for choice in matters of reproduction.

4. Senses, imagination and thought: being able to use the senses, to imagine, think, and reason-and to do these things in a "truly human" way.

5. Emotions. Being able to have attachments to things and people outside ourselves;

6. Practical reason: being able to form a conception of the good and to engage in critical reflection about the planning of one's life.

7. Affiliation: a. being able to live with and toward others; b. having social bases of self-respect and nonhumiliation.

8. Other species: being able to live with concern for and in relation to animals, plants, and the world of nature.

9. Play being able to laugh to play, to enjoy, recreational, activities.

10. Control over one's environment: a. political: being able to participate effectively in political choices that govern one's life; b. material: being able to hold property. ${ }^{25}$

By posing ten central capabilities, however, Nussbaum faces the charge of cultural imperialism. Nussbaum's list has been critiqued as heavily biased by liberal culture. The notion of capabilities is embedded in culture. In order to make a 
set list that fits for all culture, it means imposing one specific view of life or goodness upon other people who live in different worldviews. Nussbaum is aware of this criticism and replies that list is an initial draft for people in other cultures to reflect in the lights of their own capabilities. Nussbaum always refers to the idea of overlapping consensus. John Rawls originally proposed this idea. He says that people with their own understanding of justice can enter public discourse and get a common understanding of the basic structure of the society. By this conviction, Nussbaum reply the relativistism as failed to get out from their monadic culture. People can critique the fact of injustice in other cultures because we have common reference to the values that we claim to be universal. For Nussbaum, society needs a normative conception of social justice, and she endorses some basic content of it. We cannot say, "I'm for justice, but any conception of justice anyone comes up with is all right with me." ${ }^{26}$ We do not come to public discussion about basic construction of society without any specific proposal on what we think the good society is. Lisa Cahill, for example, supports Nussbaum's position by showing that some western feminists fail to acknowledge the practice of injustice in other traditions because of reluctance to be charged with imposing one's own values upon other. ${ }^{27}$

Nussbaum also differentiates between the issue of justification and the issue of implementation. By the issue of justification, she means that people across the world will justify her list as a good basis for political principles, regardless their different ethnic or religious background. They may come with different religious opinions why society must respect the capability to speak freely, but in the end, the multicultural society will agree that society must protect it. But, it will be different in the issue of implementation from one society to other. Some will secure it without limit; others will make a certain arrangement so that the freedom to speak will not make the society prone to greater cultural conflict. Cultural diversity requires respect-fulness between cultures.
Nussbaum also defends her list as a basic open-ended proposal in public discourse, rather than letting the public it self make adjustments by adding to it or prioritizing which capabilities need more attention or are more urgent. Lisa Cahill amends the list by adding two other capabilities to the list, namely: kinship and religion. Being able to be a part of the family and being able to express their religious belief or belong to one religious group also constitutes someone's capability and longing. The capability approach, then, must receive their contextuality and justification in public discussion.

\section{Choice: Freedom to Flourish}

As mentioned before, the capability approach put much attention on the role of choice. Nussbaum claims that the capability approach is in line with the deontological view of person. Person is the end in her self. She criticized consequentialism, which seeks the maximum conditions for best consequences. Even if it starts from a certain conception of the good, consequentialism can easily slide into abusing every necessary means for better or best outcomes. On the other hand, Kant vigorously denied any political assumptions, that violates person' fundamental entitlement. Deontology starts from the question of right and how in pursuing happiness we do not neglect the principle of impartiality and respect. The debate between "end justifies means" is at the heart of it, and Nussbaum's capability approach places her lineage with Kant. She is concerned that the consequentialist view of development will sacrifice some member of the community who can be categorized as a burden: the old people, or those with disabilities. Consequentialists will ask, "why must society give attention to these kind of people who will affect lesser good outcomes for the society?". This is what happens when the Nazi's policy seeks to eliminate "the defect of the society". Nussbaum sees that the consequentialist justification to use every means for best outcomes will also justify injustice in the society in the name of best outcome. But, she doesn't reject the importance of outcomes in the political 
system. In order to get the best outcome, society must respect the basic rights of the people, and respect every process in the making of good outcomes.

What makes the person as central or as "the end for him self" is his ability of make choices. From the first part of this paper, we know that the Greek polis provided many resources in educating the youth in order to make them capable to make choices. Trained by this basic capability, the youth can take every available opportunity to be or to do. The ability to make choices requires the protection of human freedom. We make cannot make a choice if we don't have freedom. Amartya Sen gives the example of "fasting and starving". In fasting, people choose not to eat, but starving happens because of lack of opportunity to get food. Development means giving people the ability to select what they think they could be or what could be done, and freedom is a space in which people can make choices. It is the reason for Sen to claim that "development as a freedom".

But, since the idea of freedom is very broad, what kind of freedom is essentially required for human flourishing? In this point, Nussbaum departs herself from Sen. Not all exercise of freedom is worthy enough to be called basic capabilities; some are essential and some are just trivial. Freedom to choose religion must not be on the same level with the freedom not to use helmet when driving motorcycle ${ }^{28}$. Some form of freedom also puts the limits on the freedom of others. Michael Walzer point it rightly in The Sphere of Justice when he noted the threat of dominance of one sphere (money) to other sphere (political society). Some freedom also requires the idea of constraint. Someone can freely perform some action in such situations because the other person is constrained not to interfere in that situation.

In this multi-layered nuance of freedom, Nussbaum concludes that we need to come to a basic list of what is the most required condition of human freedom. The ten basic capabilities address the question of freedom in the face of social justice: the freedom to have and use leisure time, the freedom in performing bodily integrity, the freedom to participate in any association. It is the duty of the government to secure these ten basic tenets of human freedom, and people have a right to demand that list to be incorporated in constitutional law.

From these various forms of freedom, affiliation and practical reason play a distinctive architectonic role. ${ }^{29}$ The good societal policy should incorporate these basic roles. Securing the freedom to use practical reason means giving a wide possibility to choose and plan their life. Promoting the freedom to affiliate means respecting the human nature as social being who need to interact with each other and build a community. For Nussbaum, these two roles are architectonic because the other forms of freedom will develop if only these two roles are secured and preserved.

\section{PART III - INTERSECTION AND DIVERGENCE}

By putting the common good theory side by side with capability approach, we can directly get the sense of intersection from these two theories, which have some common basic assumptions on how persons relate with the society. We can say that both theories originally come from the same source, on Aristotelian reading of historicity. While the common good in Catholic social tradition departs more from the Aristotelian metaphysical system, the capability approach draws more attention to the anthropological notion of human flourishing.

I find three interesting points of intersection and divergence from comparing the common good theory with the capability approach.

\section{Participation in Perfection Based on Human Capability}

The underlying concept in the common good is the Thomistic teleology of perfection. The common good for Aquinas is not just the condition that everyone can flourish fully, but as the final end of human inclination toward God. The final state of the common good is visio beatifica when 
human being can "see face to face with" God.

But, to be able to engage in the arduous journey of perfection, we must acknowledge our capability to engage in that process. Thus, the Thomistic teleology of goodness must be based on the anthropological assessment of human capability. Without being grounded in human capability to flourish and to attain the goodness, this teleological inclination is prone to be formalistic and far away from historical reality ${ }^{30}$.

The capability approach can be useful for the common good theory to trace down many areas of the incarnate good, goodness that is present in specific human culture and not just the abstract goodness across human history and time: goodness in our bodily integrity, goodness in leisure, goodness in political participation, goodness for having practical reason, goodness in living peacefully with other creatures. Nussbaum's criticism of the GDP approach can be interpreted also as the criticism of "dry and empty universal goodness", which does not count everybody as a unique person, as the end in herself.

The era of "teleology from above" in my opinion is over. But, we can start the "teleology from below", from the experience of each and every person's capability to attain goodness and to flourish. I think that by making capabilities approach as the anthropological foundation, the theory of the common good can give a major contribution in directing cross cultural collaboration for a better world.

Of course Nussbaum will reject the "teleology from below" because of her conviction on a freestanding moral theory. But, then we can ask: when Nussbaum rejects the order of being -that justifies human beings as superior to animal- and propose the animal capability, does it mean that there's also a "metaphysical assumption" on equality of creatures? If we rely only on the "intuitive assumption of common humanity" as she proposes, our intuition will easily say that human is superior than animal. ${ }^{31}$ In order to say the opposite, we need more than "intuitive assumption" on creatures. The Christian tradition calls it: the natural law.

The natural law can be interpreted not merely as an abstract and deductive metaphysical thinking, but also in more inductive way, by paying attention on the various experiences of God's presence in human history. When God, the supreme good, creates the world, God shares her own goodness to the world. ${ }^{32}$ The creation becomes the image of God, because by looking the goodness in other creatures, human being can see, even it is limited, the reflection of eternal goodness of God. Because human being can see the image of their Creator in other creation, they will respect them and will not do harm to them. The natural law tradition will say, "Do good and avoid evil." By doing good to other creature, a person respects the reflection of goodness in other creature. On this very point, Catholic tradition of natural law can give solid foundation on Nussbaum's passion of natural right.

\section{Contextualizing Capabilities as Stimulus for Intellectual Solidarity}

Proposing a theory of the common good "from below" in this pluralist society is also risky. There is a major challenge around our capacity to attain a single conception of the common good, when people come with their rich diverse backgrounds. Catholic thinkers are being charged to be "too optimistic" on human capacity in attaining a coherent view on idea of the good. One major critique of the common good theory comes from John Rawls. Rawls said that one criteria of public discourse is understandability, when our partner understands what we are talking about and can agree or disagree with that. Engaging public discourse starting from particular conception of good will eliminate other people who does not share the same understanding- from the agora. So, Rawls use the idea of "public reason" which is so thin, leaving aside all our cultural background, so that other people could understand what we talk about and engage in public discourse. Therefore, by proposing public reason, Rawls refuses to talk about the common good. 
Although communitarianism rejects Rawls public reason since all people are always embedded in their rich cultural context, they are in agreement with Rawls about the impossibility to think about the common good in multicultural society. Communitarianism has a tendency of cultural relativism. Finding the common good means justifying the universal value of human culture, which is contrary to their conviction, because any claim on universal values will reject the uniqueness of tradition.

In this debate on universal or situated good, the idea of intellectual solidarity can be very useful, not to make it an "either/or" situation but as an arena for civilized conversation between cultures. As Nussbaum said, cultural relativism is entrapped in the monadic notion of good, as if the idea of goodness is incommunicable. Cultural relativism has also failed to address the problem of "adaptive preference" within one's own culture. In the heart of the capability approach and the common good, there is an optimism of human possibility to make "conversation within and between culture", to find a sense of connectedness, and finally to engage in the global responsibility. As the world is increasingly connected, we require a more robust vision of the goodness that we can share with others. The experience of interdependence challenges us to reflect on how the contextual human flourishing can be supported by global community

The idea of communio in the common good theory and Nussbaum's idea on the architectonic role of affiliation are grounded in the human ability to connect with each other. Then, ten central capabilities can be interpreted as the trajectory of communal conversation: how political arrangements in the society can help every member or group to attain their fullness by securing these capabilities. I strongly agree with Lisa Cahill's argument not to abandon the ten areas of capabilities proposed by Nussbaum, but to amend and contextualize the list intra and extra community. Animal rights are a good vision but it seems not urgent and too bourgeois in developing countries that still struggle for more openness and accountability in political and economic activity.

\section{The Embeddedness of Choice}

Since the capability approach puts choice as central, in what degree does society affect our ability to make choices? I don't believe in black and white opposition between determinism-freedom, as if it is a matter of either personal freedom or societal deterministic. We find a societal influence in our capability to choose, and we notice also individual contributions to the societal construction. The common good gives more nuances to this topic, rather than in the capability approach. Since the capability approach is affiliated with the Kantian deontological point of view, I found that their reflection of how this back-forward relationship between personal freedom and society worked was limited.

Charles Taylor shows this awareness by analyzing the human phenomenon of language. ${ }^{33}$ Human language shows two sides, freedom and community, of the same coin. First, human being cannot be separated from the network of relations as shown by a person's speech acts. Someone can speak a language because he is part of a community. There is no language outside the community. Second, although he is part of the community, he still has freedom and creativity to explore a language to convey meaning, his hopes, and his ideals. Communities allow languages to happen, but in the end it is "I" who speaks. There is no conflict between freedom and community, because these two things are mutually presupposed. Eliminating one of them either freedom or community- will only lead to totalitarianism, whether individualist totalitarianism -which adores freedom at all cost- or communalist totali-tarianism -when togetherness suppresses initiatives and personal freedom.

Taylor's phenomenology of human language shows in some degree that, we live in a chosen society. It is the mothers representing the community- who chooses the language for their baby. Of course, 20 years later she can speak German, French, 
Swahili, but the "taste of mother tongue" cannot fade away. We find the cultural embeddedness, either great or low, and it affects our sense of choices.

The capabilities approach was right when they criticized "adaptive preference" in the society, and we should also recognize the hidden injustice in culture. But, at the same time, the capabilities approach does not recognize that the ability to choose is itself affected by cultural preferences. In this situation, the common good approach can give more attention to that reality rather than the capability approach.

\section{CONCLUSION: A CAPABILITY TO PROMOTE THE COMMON GOOD}

Jacques Maritain quotes Pius XII encyclical Mystici Corpiris Christi as the Magna Charta of the Christian humanism:

in natural body, the principle of unity so unites the parts that each lack its own individual subsistence; on the contrary in the Mystical Body that mutual union, though intrinsic, links the members by a bond which leaves to each intact his own personalit all different members are ultimately destined to the good of the whole alone; while every moral association of men, if we look to its ultimate usefulness, is in the end directed to the advancement of all and of every single member. For they are persons, utpote personae sunt. ${ }^{34}$

The experience of lackness must not be interpreted as badness. Lackness can also become the drive of progression, a passion to come out from our monadic self to meet each other. Martha Nussbaum loves to quote Marin Luther King's "human dignity like a check which has come back marked "insufficient funds." ${ }^{35}$ Conditions of insufficiency develop our awareness that these conditions should not be allowed to happen again, and our constitution must protect various areas where our humanity prevails. If we always think that we are abundant enough as a society, the sensitivity to move forward to the Mystical Body will not be present.

The experience of being lacking drives us to look to our arduous end, to the fullness of humanity. It is not in the blessed future, but in every single action to engage with other in the society, to draw the goodness that present in human history. Since it is already present in human history, even not yet complete, we have the capability to pursue and promote it. In this spirit, we can define development as a call to secure and flourish our capability to promote the common good. That make us a human person, utpote personae sunt!

\section{Paulus Bambang Irawan}

Graduate of Doctoral Programs in Boston College School of Theology and Ministry, Massachusetts,

USA. Lecturer at the Faculty of Theology, University of Sanata Dharma Yogyakarta.

Email:bambs@usd.ac.id

\section{Endnotes}

1 Amartya Sen, Development as Freedom (New York: Knopf, 1999).

2 Marta Nussbaum, "Aristotelian Social Democracy", in Liberalism and the Good, edited by R. Bruce Dauglass, Gerald R. Mara, and Henry S. Richardson (New York: Routledge, 1990), 203-252.

3 David Hollenbach, The Common Good and Christian Ethics (Cambridge, Mass.: Cambridge University Press, 2002), 6-7.

4 Sussane M. DeCrane. Aquinas, Feminism and The Common Good (Washington D.C.: Georgetown University Press, 2004), 43-44.

5 Thomas Aquinas. Expositio Libri De Hebdomadibus I.2. cited in John Rziha, Perfecting Human Actions: St. Thomas Aquinas on Human participation in Eternal Law (Washington D.C.: The Catholic University of America Press, 2009), 8.

6 Thomas Aquinas, Quaestiones Disputate De Veritate, Q.21, a.2; cited in Sussane M. DeCrane, Aquinas, Feminism and The Common Good, 50.

7 Thomas Aquinas, Summa Theologica I.II.Q.90 a.2.

8 Thomas Aquinas, Summa Theologica, II.II.Q.47 a.10; cited by Jacques Maritain, The Person and Common Good (Indiana: University of Notre Dame, 2009), 47.

$9 \quad$ Mater et Magistra 65

10 Inge Kaul, Isabelle Grunberg and Marc A. Stern "Defining Global Public Goods," Global Public Goods: International Cooperation in the 21st Century (New York: Oxford, 1999), 2-19.

11 Gaudium et Spes 26, Mater et Magistra 53.

12 David Hollenbach, "The Common Good Revisited," Theological Studies 50 (1989): 70.

13 David Hollenbach, The Common Good and Christian Ethics, 138.

14 David Hollenbach, "Religion and Political Life", Theological Studies 52 (1991):88.

15 Cicero, De Re Publica, I, SSV, 39; cited in David Hollenbach, The Common Good and Christian Ethics, 65. 
16 Grace Y. Kao. Grounding Human Right, (Washington D.C: Georgetown University Press, 2011), 104

17 "A person who is going to make a fitting inquiry into the best political arrangement must first get clear about what the most choiceworthy life is - for if this is unclear, the best political arrangement mus remain unclear also" Politics 1323a17-19, cited in Martha Nussbaum, Aristotelian Social Democracy, 208.

18 Nussbaum, Aristotelian Social Democracy, 209.

19 "It is evident that the best politeia is the arrangement according to which anyone whatsoever might do best and live a flourishing life". Aristotle, Politics 1324a23-5; cited in Martha Nussbaum, "Nature, Function, and Capability: Aristotle on Political Distribution" in Marx and Aristotle, ed. G. McCarthy (Savage, MD: Rowman and Littlefield, 1992), 176

20 "It is the job of the excellent lawgiver to consider, concerning a city and a class of human beings and every other association, how they will partake in the flourishing living that is possible for them." Aristotle, Politics, $1325 \mathrm{a} 7 \mathrm{ff}$.; Nussbaum, Aristotelian Social Democracy, 177.

21 Nussbaum, Aristotelian Social Democracy, 175

22 "We believe that no citizen should be lacking in sustenance support. As for the common meal, everyone agrees that they are a valuable institution in a well ordered city". Aristotle, Politics 1329b39 ff. See also Politics 1330b11"The things that we use most of and most frequently where our bodies are concerned, these have the biggest impact on health. Water and air are things of that sort. So, good political planning should make some decisions about these things", cited in Martha Nussbaum, Aristotelian Social Democracy, 204.

23 In Politics 1271a26-37, 1272a12-21, Aristotle criticized people of Sparta who fail to support the poor to participate in common meal and even make a penalty for the poor who cannot pay for all civic participation. Nussbaum, Aristotelian Social Democracy, 204.

24 Martha Nussbaum, Creating Capabilities (Cambridge Mass.: The Belknap Press of Harvard University Press, 2011), 22.

25 Martha Nussbaum, Creating Capabilities, 33-34.

26 Martha Nussbaum, "Capabilities as Fundamental Entitlements" in Capabilities Equality: Basic Issues and Problems, ed. Alexander Kaufman (New York: Routledge, 2006), 58.

27 Lisa Sowle Cahil, Sex, Gender and Equality, cited in Sussane M. DeCrane, Aquinas, Feminism and The Common Good, 37.

28 Martha Nussbaum, "Capabilities as Fundamental Entitlements", 56.

29 Martha Nussbaum, Creating Capabilities, 39.

30 Jürgen Motlmann criticize the Thomistic tendency to put complete goodness in the future and but not quite embed it in the reality of the present, because human being is always in the status in via, or in the journey to God. Jürgen Moltmann "Christian Hope: Messianic of Transcendent: A Theological
Discussion with Joachim of Fiore and Thomas Aquinas", Horizon 12/2 (1985): 328-348.

31 For further discussion on the critique to Nussbaum claim on a freestanding moral theory see Grace Y.Kao, Grounding Human Rights in a Pluralist World, 125-129.

32 Thomas Aquinas, Summa Theologica, I.Q.5 a.5.

33 David Hollenbach, "A Communitarian Reconstruction of Human Rights" in Catholicism and Liberalism: Contributions to American Public Philosophy, edited by R. Bruce Douglass \& David Hollenbach (Cambridge, Mass.: Cambridge University Press, 1997), 130.

34 Mystici Corporis Christi, cited in Jacques Maritain, The person and Common Good, 29, f22.

35 Martha Nussbaum, Creating Capabilities, 30.

\section{BIBLIOGRAPHY}

DeCrane, Sussane M. Aquinas, Feminism and The Common Good. Washington D.C.: Georgetown University Press, 2004.

Hollenbach, David. "The Common Good Revisited." Theological Studies 50 (1989): 70-90.

"Religion and Political Life."
Theological Studies 52 (1991): 60-88.

"A communitarian reconstruction of human rights" in Catholicism and Liberalism: Contributions to American Public Philosophy, eds. R. Bruce Douglass \& David Hollenbach. 130-158. Cambridge, Mass.: Cambridge University Press, 1997.

The Common Good and Christian Ethics. Cambridge, Mass.: Cambridge University Press, 2002.

Kao, Grace Y. Grounding Human Right. Washington D.C.: Georgetown University Press, 2011.

Kaul, Inge, Isabelle Grunberg and Marc A. Stern "Defining Global Public Goods" in: Inge Kaul, Isabelle Grunberg, Marc A. Stern, Global Public Goods: International Cooperation in the 21st Century. 10-30. Oxford, UK: Oxford University Press, 1999. 
Maritain, Jacques. The Person and Common Good. Indiana: University of Notre Dame, 2009 edition.

Nussbaum, Marta. "Aristotelian Social Democracy", in Liberalism and the Good, eds. R. Bruce Dauglass, Gerald R. Mara, and Henry S. Richardson. 203-252. New York: Routledge, 1990.

"Nature, Function, and Capability: Aristotle on Political Distribution" in Marx and Aristotle, ed. G. McCarthy. 175-211. Savage, MD: Rowman and Littlefield, 1992.

"Capabilities as Fundamental Entitlements" in Capabilities Equality: Basic Issues and Problems, ed. Alexander Kaufman. 44-70. New York: Routledge, 2006.
- Creating Capabilities. Cambridge Mass.: The Belknap Press of Harvard University Press, 2011.

Rziha, John. Perfecting Human Actions: St. Thomas Aquinas on Human participation in Eternal Law. Washington D.C.: The Catholic University of America Press, 2009.

Sen, Amartya. Development as Freedom. New York: Kropt, 1999. 